\title{
Quantification and Source Identification of Atmospheric Particulate Polycyclic Aromatic Hydrocarbons and their Dry Deposition Fluxes at Three Sites in Salvador Basin, Brazil, Impacted by Mobile and Stationary Sources
}

\author{
Gisele O. da Rocha, ${ }^{a, b, e}$ Wilson A. Lopes, ${ }^{a, e}$ Pedro A. de Paula Pereira, ${ }^{a, b, e}$ Pérola de Castro Vasconcellos, ${ }^{c, e}$ \\ Fábio S. Oliveira, ${ }^{d}$ Luiz S. Carvalho, ${ }^{a}$ Liliane dos Santos Conceição ${ }^{a}$ and Jailson B. de Andrade ${ }^{a, b, e, *}$ \\ anstituto de Química, Universidade Federal da Bahia, Campus de Ondina, 40170-115 Salvador-BA, Brazil \\ ${ }^{b}$ Centro Interdisciplinar de Energia e Ambiente, Universidade Federal da Bahia, 40110-040 Salvador-BA, Brazil \\ 'Instituto de Química, Universidade de São Paulo, Cidade Universitária, Butantã, 05508-900 SãoPaulo-SP, Brazil \\ ${ }^{d}$ Centro de Ciências da Saúde, Universidade Federal do Recôncavo da Bahia, Santo Antônio de Jesus-BA, Brazil \\ eInstituto Nacional de Ciência e Tecnologia, INCT, de Energia e Ambiente, Universidade Federal da Bahia, \\ 40170-290 Salvador-BA, Brazil
}

\begin{abstract}
O presente trabalho apresenta o estudo sobre 16 HPAs prioritários em material particulado atmosférico de três sítios próximos a Salvador-BA: (i) Estação da Lapa, estação de ônibus da Região Metropolitana de Salvador; (ii) Porto de Aratu, impactado por intenso movimento de matériasprimas e (iii) Bananeira, localizado na Ilha de Maré, vilarejo que tem como principais atividades a pesca e artesanato. Resultados mostraram que o $\mathrm{BbF}\left(0,130-6,85 \mathrm{ng} \mathrm{m}^{-3}\right)$ foi o HPA com as concentrações mais elevadas em Aratu e Bananeira e CRY (0,075-6,85 $\left.\mathrm{ng} \mathrm{m}^{-3}\right)$ apresentou nível mais elevado na Lapa. As fontes de HPAs nos sítios estudados foram principalmente de origem antrópica, tais como veículos de pequeno e grande portes, carregamentos do porto, ressuspensão de partículas do solo, queima de diesel das embarcações e a queima de carvão e madeira para produção de energia.
\end{abstract}

The present work has aimed to determine the 16 US EPA priority PAH atmospheric particulate matter levels present in three sites around Salvador, Bahia: $(i)$ Lapa bus station, strongly impacted by heavy-duty diesel vehicles; (ii) Aratu harbor, impacted by an intense movement of goods, and (iii) Bananeira village on Maré Island, a non vehicle-influenced site with activities such as handcraft work and fisheries. Results indicated that BbF $\left(0.130-6.85 \mathrm{ng} \mathrm{m}^{-3}\right)$ is the PAH with highest concentration in samples from Aratu harbor and Bananeira and CRY (0.075-6.85 $\left.\mathrm{ng} \mathrm{m}^{-3}\right)$ presented higher concentrations at Lapa station. PAH sources from studied sites were mainly of anthropogenic origin such as gasoline-fueled light-duty vehicles and diesel-fueled heavy-duty vehicles, discharges in the port, diesel burning from ships, dust ressuspension, indoor soot from cooking, and coal and wood combustion for energy production.

Keywords: PAH, GC-MS, $\mathrm{PM}_{10}$, TSP, aerosol dry deposition fluxes, air pollution

\section{Introduction}

Particulate matter plays a significant role in the chemistry of the atmosphere and in human health. Several epidemiological studies have associated daily exposures to particulate matter with increased incidences of premature death, chronic asthma and increased hospital admissions as well as respiratory problems in children. ${ }^{1-3}$ While their

*e-mail: jailsong@ufba.br constitution may vary from place to place, the sources of particulate matter are numerous, from natural origin (mainly vegetation and dust resuspension, among others) to different kinds of human activities, such as disposal of petroleum residues, waste incineration, energy production, vehicular emissions and agricultural slash burning. ${ }^{1-4}$

Vehicle exhaust aerosols contain carbonaceous particles that are associated with a complex mixture of compounds. Special attention has been given to particles emitted by diesel engines, due to the numerous in vivo and in vitro 
studies establishing their adverse effects on human health. ${ }^{4-6}$ Among the several organic and inorganic species which are associated with diesel exhaust particles, including monoand poly-functional organic compounds resulting from gas-to-particle conversion mechanisms, hydrocarbons with high molar mass, such as polycyclic aromatic hydrocarbons (PAH) and their oxy- and nitro-derivatives, are of particular interest. ${ }^{4,5,79}$ PAH are ubiquitous and abundant pollutants that are emitted from several natural and/or anthropogenic sources and may be present in the atmosphere, hydrosphere and lithosphere. ${ }^{10-14}$ The widespread occurrence of PAH is largely due to their formation and emission during incomplete combustion of petrogenic materials such as oil and coal as well as non-petrogenic sources such as wood burning ${ }^{3,15-19}$ as well as biomass burning due to agricultural practices. ${ }^{20}$ In urban areas, exhausts from diesel and gasoline vehicles play an important role in PAH emissions. On roads, emissions of PAH are strongly influenced by heavy-duty diesel vehicles. ${ }^{21}$

Many PAH are regarded as priority pollutants by both the United States Environmental Protection Agency and the European Community. While no standard currently exists in Brazil for PAH concentrations in ambient air, the U.K. Government Expert Panel on Air Quality Standards is considering an air quality standard for PAH of $0.25 \mathrm{ng} \mathrm{m}^{-3}$ (annual mean) to be achieved by December 2010.22 It should be mentioned that particulate $\mathrm{PAH}$, measured in urban air and inside roadway tunnels, have been found in the respirable size range with a significant amount in the ultrafine fraction of the particulate matter. ${ }^{10,23-26}$

The aim of the present work was to determine the atmospheric concentrations and profiles of 16 particlephase US EPA priority PAH pollutants, present at the same three sites previously studied, ${ }^{27}$ namely: $(i)$ Lapa bus station, strongly impacted by heavy-duty diesel vehicles and which has been already characterized for high molar mass $n$-alkanes and polycyclic aromatic hydrocarbons; $;{ }^{28}$

(ii) Aratu Harbor, impacted by an intense movement of goods, including metal ores and chemicals and near industrial centers and; (iii) Bananeira Village, located on Maré Island, a non vehicle-influenced site, with activities such as handcraft work and fisheries, although placed near the port (Figure 1). Even though Lapa bus station was studied ${ }^{27,28}$ some years ago, nowadays this station has undergone architectural adjustments (previously it was an indoor facility and now there is a "half-opened" space that makes pollutant dispersion more possible). Fuel composition has been changed and aged bus fleet provides conditions that might affect particle-associated PAH production, justifying the present study. Moreover, to our knowledge, this is the first time that PAH were

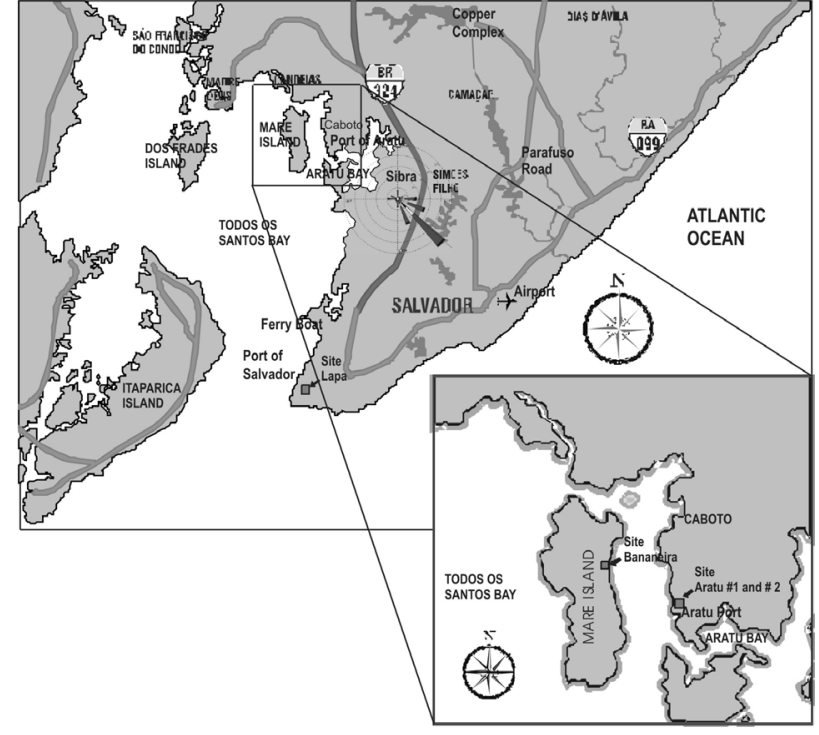

Figure 1. Map of Todos os Santos Bay locating the collecting sites.

studied in Bananeira and Aratu Harbor (both sites are part of Todos os Santos Bay). Also, there is an increasing interest in the installation of other industries, hotels and resorts that would possibly result in modifications of natural environment of Todos os Santos Bay and this also justifies our work since the previous study was done before these modifications. Our results could therefore be considered in future studies in order to make useful comparisons.

\section{Experimental}

\section{Sampling sites}

\section{Lapa bus station}

The Lapa bus station is in downtown Salvador city in a region featured by heavy commerce and service activities, with several stores, small office buildings and a large mall in its neighborhood. The station is composed of three levels: the first one being located underground and the second at ground level, with total areas of about 13,920 $\mathrm{m}^{2}$, each one has 5 platforms for arrivals and departures of urban heavy-duty diesel buses. The third floor is occupied by small stores, cafeterias and the administration services. Samples $(n=36)$ of $\mathrm{PM}_{10}$ were collected between 16-28 July 2005 on quartz filters $(22.8 \times 17.7 \mathrm{~cm}$, Energética, RJ, Brazil) by using a $\mathrm{PM}_{10}$ Hi-Vol sampler (Energética, RJ, Brazil and Thermo Andersen, USA) on the underground bus platform. Sampling periods were 4-6 h during morning/ afternoon and 8-10 $\mathrm{h}$ during the night (weekdays) or $24 \mathrm{~h}$ (during weekends) under average sampling flow rate of $1.14 \mathrm{~m}^{3} \mathrm{~min}^{-1}$. 


\section{Aratu Harbor}

Aratu Harbor, in Todos os Santos Bay, about $50 \mathrm{~km}$ away of Salvador, possesses about $60 \%$ of total operations of ports in the Salvador region by supporting transportation of manufactured products from both the Industrial Center of Aratu (CIA) and the Petrochemical Complex of Camaçari. Its average temperature is $26^{\circ} \mathrm{C}$ and the predominant winds are NE (3-37\%), E (3-52\%) and SE (3-50\%). In this semiurban site, particles were simultaneously sampled in two size fractions: TSP $\left(\mathrm{d}_{\mathrm{p}} \leq 100 \mu \mathrm{m}\right)$ and $\mathrm{PM}_{10}$ by locating the Hi-Vol samplers at average flow rates of 1.16 and $1.14 \mathrm{~m}^{3} \mathrm{~min}^{-1}$, respectively, in two different points: Aratu\#1 (7 samples) from near an office building and Aratu\#2 (8 samples) from an open place (Figure 1). The samples were collected from October to November 2004, in sampling periods of 24 hours each.

\section{Bananeira Village}

Bananeira Village, on Mare Island, located in Todos os Santos Bay, is a remote site where fisheries and handcraft activities dominate. This place, depending on the wind direction and other meteorological conditions, receives air masses (and also emissions) from an industrial center (CIA) and from the Petrochemical Complex of Camaçari and thus its $c a .1000$ inhabitants may possibly suffer consequences as a result of them. TSP samples $(n=14)$ of $24 \mathrm{~h}$ periods, using a TSP Hi-Vol at a flow rate $1.16 \mathrm{~m}^{3} \mathrm{~min}^{-1}$, were collected in September-October 2005.

\section{Cleaning-up procedure and GC-MS analysis}

After each sampling, filters were conserved in aluminum foil envelopes and inside sealed plastic bags until weighing and analysis. Gravimetric determinations were carried out as described in Method IO-3.1, 1999. ${ }^{29}$

Extraction of the PAH from filters was according to the method developed previously. ${ }^{30}$ Briefly, a $47 \mathrm{~mm}$ diameter section of each filter was cut and placed into $10 \mathrm{~mL}$ amber flasks with $4 \mathrm{~mL}$ of a 3:1 acetonitrile/dichlorometane mixture (HPLC grade J. T. Baker, USA) being extracted for 10 minutes under ultrasonication. Extracts were filtered through $25 \mathrm{~mm}$ diameter filter discs $(0.45 \mu \mathrm{m}$ PTFE membrane units, Millex, Millipore, Bedford, USA), then allowed to dry under a gentle $\mathrm{N}_{2}$ flux and finally being redissolved in $100 \mu \mathrm{L}$ acetonitrile. Then, $1 \mu \mathrm{L}$ aliquots were injected into the GC-MS system. Recoveries of 16 priority PAH from SRM 1649 (NIST, Washington, DC) were found to vary from $45 \%$ (fluorene) to $107 \%$ (dibenz $[a, h]$ anthracene) with an overall mean recovery of $80 \% .^{30}$

GC-MS-SIM analyses were performed as described elsewhere. ${ }^{31}$ Briefly, a model QP2010 GC-MS system with
AOC-20i autosampler (Shimadzu, Japan), and a Elite5MS GC column $(30 \mathrm{~m} \times 0.25 \mathrm{~mm}$ dia. $\times 0.25 \mu \mathrm{m}$ film thickness $)$ (Perkin Elmer, USA). Quantification was carried out through external calibration curves constructed with eight different concentration levels. Limits of detection ranged from 3 to $8 \mathrm{pg} \mathrm{m}^{-3}$ and limits of quantitfication (LOQ) from 4 to $9 \mathrm{pg} \mathrm{m}^{-3}$.

Temperature programming was: (i) $70{ }^{\circ} \mathrm{C}(2 \mathrm{~min}) \rightarrow$ $200{ }^{\circ} \mathrm{C}\left(30{ }^{\circ} \mathrm{C} \min ^{-1}\right) \rightarrow 200{ }^{\circ} \mathrm{C}(5 \mathrm{~min}) \rightarrow 300{ }^{\circ} \mathrm{C}$ $\left(5.0{ }^{\circ} \mathrm{C} \mathrm{min}-1\right) \rightarrow 300{ }^{\circ} \mathrm{C}(1.67 \mathrm{~min})$ for a total of 33 minutes of running; (ii) the injector temperature was: $310^{\circ} \mathrm{C}$ using the splitless injection mode; (iii) the transfer line was at $280{ }^{\circ} \mathrm{C}$; (iv) the ion source was at $250{ }^{\circ} \mathrm{C}$, and (v) the electron impact energy was $70 \mathrm{eV}$. Detection and identification of each PAH was achieved via the two most abundant ions: naphthalene (NAP)-128, 102; acenaphthalene (ACY)-152, 76; acenaphthene (ACE)-153, 76; fluorene (FLU)-166, 82; phenanthrene (PHE)-178, 152; anthracene (ANT)-178, 89; fluoranthene (FLT)-202, 101; pyrene (PYR)-202, 101; benz[a]anthracene (BaA)-228, 114; chrysene (CRY)-228, 113; benzo[b]fluoranthene (BbF)-252, 126; benzo[ $k]$ fluoranthene (BkF)-252, 126; benzo $[a]$ pyrene (BaP)-252, 126; indeno[1,2,3-c,d]pyrene (IND)-276, 138; dibenz[a, $h$ anthracene (DBA)-278, 139; benzo $[g, h, i]$ perylene $(\mathrm{BgP})-276,139$, matching them to their respective retention times.

\section{Statistical analysis}

Experimental data were analyzed by calculating the Spearman's correlation coefficients using STATISTICA software (StatSoft, USA), version 6.0. Furthermore, principal component analysis (PCA) and cluster analysis (CA), using Ward's method and Euclidian distances, were also performed. The calculations (PCA and CA) were achieved using individual experimental values of each of the $16 \mathrm{PAH}\left(\mathrm{ng} \mathrm{m}^{-3}\right)$ for each sample and sampling site.

\section{Results and Discussion}

\section{TSP and PM ${ }_{10}$ particles in air and PAH concentrations}

As discussed in a previous paper, ${ }^{27}$ Aratu Harbor was the only site in which both TSP and $\mathrm{PM}_{10}$ particles were collected simultaneously. The F test was applied to two collection sites to see if they could be considered similar. ${ }^{26}$ They are statistically different and then discussed separately. Furthermore, regarding different collection periods for each site, it was not our intention to directly do inter-site comparisons. Thus, the only comparison made 
is for TSP and $\mathrm{PM}_{10}$ samples from Aratu Harbor. We have adopted the same approach in the present study.

All of the EPA priority PAH were identified in samples from the four sites of the present study. In all sites PAHs with higher molar mass and lower vapor pressure (those ones with 4-6 benzene rings, namely $\mathrm{BaA}, \mathrm{CRY}, \mathrm{BbF}$, $\mathrm{BkF}, \mathrm{BaP}, \mathrm{IND}, \mathrm{DBA}$ and $\mathrm{BgP}$ ) reached higher particle phase concentrations and those with 2-3 rings such as NAP, ACY, ACE and FLU were scarcely found. Because this work has considered the particle-phase only it is necessary to remember that atmospheric levels of the most volatile PAH (such as NAP, ACY, ACE and FLU) are underestimated since they are preferentially present in the gaseous phase. Nonetheless, considering all sampling days, $\mathrm{BbF}$ (ranging from 0.130-6.85 $\mathrm{ng} \mathrm{m}^{-3}$ ) is the PAH with the highest concentration in samples from Bananeira and Aratu Harbor CRY (from 0.075-6.85 $\mathrm{ng} \mathrm{m}^{-3}$ ) presented higher concentrations in the Lapa Bus Station. PAH arithmetic mean concentrations were higher in TSP than in $\mathrm{PM}_{10}$, showing a similar PAH distribution in Aratu \#1 and Aratu \#2 in spite the fact that lower PAH concentration levels belonged to Aratu \#2. This could be due to differences of the air mass trajectories of both places, as discussed elsewhere. ${ }^{27}$ Aratu Harbor, during TSP and $\mathrm{PM}_{10}$ sampling, received in its terminals disembarkations of many kinds of goods, including coke, charcoal and petroleum derivatives. Additionally, the diesel oil used to fuel the ships probably contributed to the PAH content of this place. Bananeiras village, on the other hand, seems to be mainly a receptor site for emissions from the Industrial Center of Aratu. Table 1 shows concentrations of particle-associated PAH $\left(\mathrm{ng} \mathrm{m}^{-3}\right)$ and some descriptive statistical information regarding TSP and $\mathrm{PM}_{10}\left(\mu \mathrm{g} \mathrm{m}^{-3}\right)$ of Lapa bus station, Aratu Harbor and Bananeira. Table 2 shows the PAH particle content of $\mathrm{PM}$ collected in this study (units in $\mu \mathrm{g} \mathrm{g}^{-1}$ ). At these sites, on average, $\Sigma$ PAH accounted for $0.005 \%$ and $0.0012 \%$ of the TSP mass for Aratu Harbor and Bananeiras village, respectively, while it was $0.008 \%$ and $0.011 \%$ of the PM10 mass of Aratu Harbor and Lapa bus station, respectively.

Contributions of carcinogenic species $(\mathrm{BaA}, \mathrm{BbF}$, $\mathrm{BkF}, \mathrm{BaP}, \mathrm{DBA}$, and IND) for the PAH content represent (in $\mu \mathrm{g} \mathrm{g}^{-1}$ ) 42.4, 25.4, 78.2, 25.2, 79.4 and 45.3 for Aratu

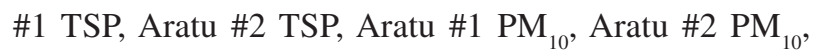
Bananeiras and Lapa, respectively. Figure 2 shows relative contributions of both carcinogenic (to which BbF, BkF and $\mathrm{BaP}$ are the major contributors) and non-carcinogenic (major contributors are BgP, CRY, and PYR) PAHs measured. At three sites amongst the four studied, the carcinogenic PAH represent the main fraction in the total PAH determined in particulate matter, with very similar

Table 1. Statistical summary of PAH, TSP and $\mathrm{PM}_{10}$ concentrations in Aratu, Bananeira and Lapa bus station

\begin{tabular}{|c|c|c|c|c|c|c|c|c|c|c|c|c|c|c|c|c|c|c|c|}
\hline \multirow[t]{2}{*}{ Site } & \multicolumn{17}{|c|}{$\mathrm{PAH} /\left(\mathrm{ng} \mathrm{m}^{-3}\right)$} & \multicolumn{2}{|c|}{$\mathrm{PM}\left(\mu \mathrm{g} \mathrm{m}^{-3}\right)^{\mathrm{a}}$} \\
\hline & & NAP & $\mathrm{ACY}$ & $\mathrm{ACE}$ & FLU & PHE & ANT & FLT & PYR & $\mathrm{BaA}$ & CRY & $\mathrm{BbF}$ & $\mathrm{BkF}$ & $\mathrm{BaP}$ & IND & DBA & $\mathrm{BgP}$ & TSP & $\mathrm{PM}_{10}$ \\
\hline \multirow{4}{*}{$\begin{array}{l}\text { Aratu\#1 TSP } \\
(\mathrm{n}=7)\end{array}$} & Mean & 0.112 & 0.036 & 0.054 & 0.045 & 0.150 & 0.048 & 0.295 & 0.336 & 0.417 & 0.871 & 3.24 & 1.10 & 1.05 & 1.37 & 0.521 & 1.45 & 182 & \\
\hline & $\mathrm{SD}$ & 0.040 & 0.008 & 0.029 & 0.004 & 0.062 & 0.009 & 0.212 & 0.223 & 0.452 & 0.606 & 2.41 & 0.867 & 0.943 & 1.07 & 0.471 & 1.15 & 87.7 & \\
\hline & $\operatorname{Max}$ & 0.146 & 0.049 & 0.105 & 0.050 & 0.252 & 0.064 & 0.676 & 0.710 & 1.41 & 1.94 & 6.37 & 2.35 & 2.78 & 3.02 & 1.40 & 3.05 & 106 & \\
\hline & Min & 0.032 & 0.026 & nd* & 0.037 & 0.079 & 0.038 & 0.147 & 0.165 & 0.158 & 0.352 & 1.03 & 0.351 & 0.261 & 0.298 & 0.117 & 0.342 & 354 & \\
\hline \multirow{4}{*}{$\begin{array}{l}\text { Aratu \#2 TSP } \\
(n=8)\end{array}$} & Mean & 0.095 & 0.030 & 0.027 & 0.040 & 0.142 & 0.056 & 0.164 & 0.174 & 0.243 & 0.561 & 1.82 & 0.701 & 0.599 & 0.879 & 0.298 & 0.992 & 169 & \\
\hline & $\mathrm{SD}$ & 0.035 & 0.004 & 0.016 & 0.004 & 0.042 & 0.021 & 0.095 & 0.085 & 0.189 & 0.561 & 1.58 & 0.663 & 0.490 & 0.730 & 0.264 & 0.857 & 46.4 & \\
\hline & Max & 0.142 & 0.035 & 0.050 & 0.045 & 0.201 & 0.103 & 0.339 & 0.328 & 0.653 & 1.79 & 5.23 & 2.17 & 1.63 & 2.28 & 0.879 & 2.72 & 95.9 & \\
\hline & Min & 0.034 & 0.023 & nd & 0.033 & 0.075 & 0.043 & 0.073 & 0.077 & 0.092 & 0.168 & 0.479 & 0.195 & 0.189 & 0.280 & 0.108 & 0.348 & 223 & \\
\hline \multirow{4}{*}{$\begin{array}{l}\text { Aratu\#1 } \mathrm{PM}_{10} \\
(\mathrm{n}=7)\end{array}$} & Mean & 0.083 & 0.029 & 0.017 & 0.039 & 0.115 & 0.044 & 0.241 & 0.241 & 0.332 & 0.649 & 2.23 & 0.879 & 0.705 & 0.869 & 0.310 & 0.961 & & 64.6 \\
\hline & SD & 0.033 & 0.007 & 0.002 & 0.004 & 0.045 & 0.009 & 0.219 & 0.191 & 0.398 & 0.549 & 1.87 & 0.819 & 0.655 & 0.716 & 0.258 & 0.806 & & 30.1 \\
\hline & Max & 0.118 & 0.042 & 0.019 & 0.046 & 0.209 & 0.061 & 0.679 & 0.545 & 1.21 & 1.75 & 4.85 & 2.16 & 1.88 & 1.89 & 0.685 & 1.96 & & 44.2 \\
\hline & Min & 0.018 & 0.022 & nd & nd & 0.083 & 0.036 & 0.089 & 0.084 & 0.109 & 0.159 & 0.399 & 0.181 & 0.178 & 0.182 & 0.103 & 0.184 & & 123 \\
\hline \multirow{4}{*}{$\begin{array}{l}\text { Aratu\#2 } \mathrm{PM}_{10} \\
(\mathrm{n}=8)\end{array}$} & Mean & 0.063 & 0.026 & 0.023 & 0.032 & 0.067 & 0.047 & 0.090 & 0.103 & 0.123 & 0.245 & 0.823 & 0.307 & 0.281 & 0.421 & 0.153 & 0.471 & & 71.7 \\
\hline & $\mathrm{SD}$ & 0.030 & 0.005 & 0.015 & 0.003 & 0.018 & 0.023 & 0.042 & 0.023 & 0.033 & 0.098 & 0.490 & 0.140 & 0.171 & 0.277 & 0.055 & 0.259 & & 13.9 \\
\hline & Max & 0.095 & 0.035 & 0.049 & 0.035 & 0.090 & 0.093 & 0.160 & 0.121 & 0.169 & 0.352 & 1.72 & 0.584 & 0.565 & 0.880 & 0.230 & 0.828 & & 49.2 \\
\hline & Min & $\mathrm{Nd}$ & 0.022 & nd & nd & 0.047 & 0.032 & 0.040 & 0.074 & 0.075 & 0.128 & 0.253 & 0.184 & 0.094 & 0.170 & 0.074 & 0.178 & & 88.2 \\
\hline \multirow{4}{*}{$\begin{array}{l}\text { Bananeira TSP } \\
(\mathrm{n}=15)\end{array}$} & Mean & 0.067 & 0.030 & 0.018 & 0.028 & 0.099 & 0.046 & 0.224 & 0.239 & 0.312 & 0.591 & 1.62 & 0.726 & 0.636 & 0.593 & 0.292 & 0.724 & 36.1 & \\
\hline & $\mathrm{SD}$ & 0.024 & 0.014 & 0.020 & 0.014 & 0.033 & 0.038 & 0.129 & 0.111 & 0.197 & 0.396 & 1.02 & 0.499 & 0.398 & 0.277 & 0.186 & 0.469 & 10.1 & \\
\hline & Max & 0.113 & 0.059 & 0.058 & 0.072 & 0.148 & 0.172 & 0.449 & 0.439 & 0.619 & 1.33 & 2.92 & 1.54 & 1.16 & 0.911 & 0.587 & 1.35 & 16.9 & \\
\hline & Min & $\mathrm{Nd}$ & 0.015 & nd & nd & 0.053 & 0.022 & 0.051 & 0.064 & 0.051 & 0.075 & 0.140 & 0.074 & 0.081 & 0.114 & nd & 0.093 & 54.5 & \\
\hline \multirow{4}{*}{$\begin{array}{l}\text { Lapa Station } \\
\mathrm{PM}_{10} \\
(\mathrm{n}=36)\end{array}$} & Mean & 0.289 & 0.066 & 0.110 & 0.130 & 0.795 & 0.189 & 0.732 & 1.32 & 1.00 & 2.625 & 1.30 & 0.487 & 1.047 & 0.728 & 0.356 & 1.056 & & 112 \\
\hline & $\mathrm{SD}$ & 0.139 & 0.047 & 0.089 & 0.120 & 0.342 & 0.169 & 0.381 & 0.674 & 0.537 & 1.96 & 1.20 & 0.427 & 0.757 & 0.620 & 0.148 & 1.037 & & 68.9 \\
\hline & Max & 0.762 & 0.178 & 0.460 & 0.745 & 1.617 & 0.829 & 1.55 & 2.74 & 2.27 & 8.64 & 6.85 & 2.44 & 3.48 & 2.88 & 0.705 & 4.45 & & 30.9 \\
\hline & Min & 0.062 & nd & nd & nd & 0.307 & 0.071 & 0.141 & 0.259 & 0.258 & 0.348 & 0.360 & 0.108 & 0.327 & nd & nd & 0.243 & & 393 \\
\hline
\end{tabular}

a Data from Pereira et al.; 27 *nd" means not detected. 
Table 2. PAH particle content of PM collected in this study (units in $\mu \mathrm{g} \mathrm{g}^{-1}$ )

\begin{tabular}{|c|c|c|c|c|c|c|c|c|c|c|c|c|c|c|c|c|}
\hline Sites & NAP & $\mathrm{ACY}$ & ACE & FLU & PHE & ANT & FLT & PYR & $\mathrm{BaA}$ & CRY & $\mathrm{BbF}$ & $\mathrm{BkF}$ & $\mathrm{BaP}$ & IND & DBA & $\mathrm{BgP}$ \\
\hline Aratu \#1 TSP & 0.6 & 0.2 & 0.3 & 0.3 & 0.8 & 0.3 & 1.6 & 1.9 & 2.3 & 4.8 & 18 & 6.1 & 5.8 & 7.6 & 2.9 & 8.0 \\
\hline Aratu \#2 TSP & 0.5 & 0.2 & 0.2 & 0.2 & 0.8 & 0.3 & 0.9 & 1.0 & 1.4 & 3.1 & 10 & 3.9 & 3.3 & 4.9 & 1.7 & 5.5 \\
\hline Aratu \#1 PM10 & 1.2 & 0.4 & 0.3 & 0.6 & 1.7 & 0.6 & 3.5 & 3.5 & 4.9 & 9.5 & 33 & 13 & 10 & 13 & 4.5 & 14 \\
\hline Aratu \#2 PM10 & 0.8 & 0.3 & 0.3 & 0.4 & 0.8 & 0.6 & 1.1 & 1.2 & 1.5 & 2.9 & 9.8 & 3.7 & 3.4 & 5.0 & 1.8 & 5.6 \\
\hline Bananeiras TSP & 1.3 & 0.6 & 0.3 & 0.5 & 1.9 & 0.9 & 4.3 & 4.5 & 5.9 & 11 & 31 & 14 & 12 & 11 & 5.6 & 14 \\
\hline Lapa PM10 & 2.7 & 0.6 & 1.0 & 1.2 & 7.3 & 1.7 & 6.7 & 12 & 9.2 & 24 & 12 & 4.5 & 9.6 & 6.7 & 3.3 & 9.7 \\
\hline
\end{tabular}
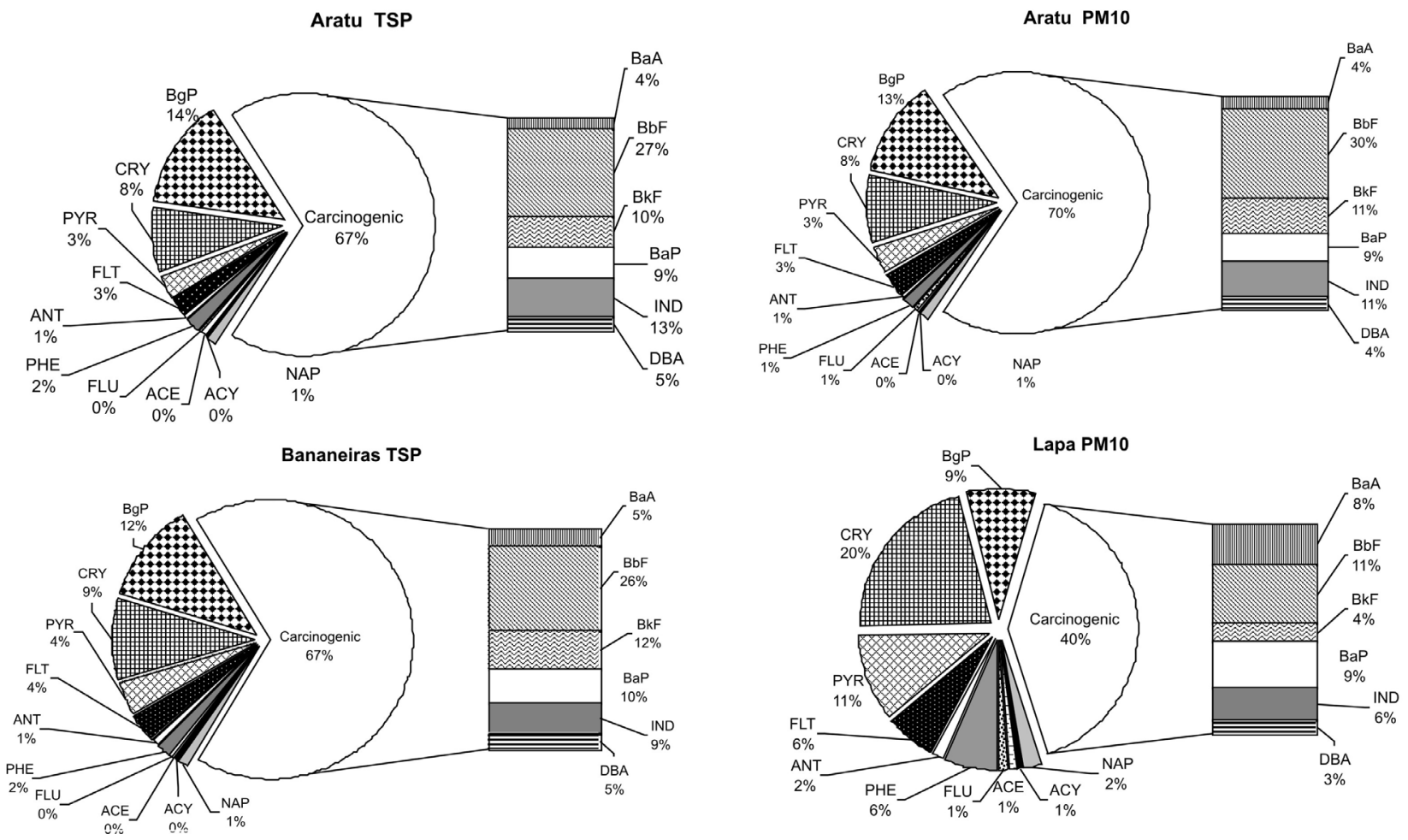

Figure 2. Percentage contributions of individual compounds, and carcinogenic species, to the total mass of measured PAH for each site studied.

percent values, (ca. 70\%), which should indicate serious health concerns. The only exception was Lapa station, where carcinogenic PAH accounted for just $40 \%$ of the total $\mathrm{PAH}$. The main reason for this was that the Lapa station had only $21 \%$ of the carcinogenic BbF, BkF and IND, against about 50\% in Aratu and Bananeiras. On the other hand, non-carcinogenic CRY and PYR accounted for $31 \%$ of the total PAH in Lapa, against only $12 \%$ in Aratu and Bananeiras. Moreover, it is necessary to consider that either nitro- or oxy-PAH derivatives, possibly generated even from those non-carcinogenic PAH species, are a more serious health hazard risk. In spite of this, concentration levels of particle-associated atmospheric PAH in the Salvador Basin are comparatively in a much lower range than reported for polluted regions. For instance, China has experienced
$\Sigma$ PAH TSP concentrations in the range of $10.7-772 \mathrm{ng} \mathrm{m}^{-3},{ }^{32}$ which represents levels 1 to 3 orders of magnitude greater than those reported in this work. Similarly, concentrations reported for South Korea (range of 22.9-410 $\mathrm{ng} \mathrm{m}^{-3}$ ) 33 show values which are 1 to 2 orders of magnitude higher than Salvador Basin. On the other hand, in comparing contributions of carcinogenic species from this study to those of Cubatão, São Paulo State, in the southeastern region of $\mathrm{Brazi}^{34}$ (this is the most industrialized Brazilian state and Cubatão is the largest industrial center in this state) showed contributions of only $59 \%$ of carcinogenic species against $67-70 \%$ for Aratu Harbor and Bananeira and $40 \%$ for Lapa bus station, even though the summed PAH mass concentrations $(\Sigma \mathrm{PAH})$ were $4.8-28.4 \mathrm{ng} \mathrm{m}^{-3}$, with a mean of $16.7 \mathrm{ng} \mathrm{m}^{-3}$, and $\Sigma \mathrm{PAH}$ accounted for $0.023 \%$ of 
the $\mathrm{PM}_{10}$ mass, in Cubatão, all values higher than those found for the Salvador Basin. Thus, we may say that the contributions of carcinogenic species were relatively high for the Salvador region.

The PAH mean concentrations in $\mathrm{PM}_{10}$ from Lapa bus station, according to the sampling day, are shown in Figure 3, and those according to the sampling period are shown in Figure 4. Since the circulation of commuting buses and people throughout the metropolitan region of Salvador city is most intense from $1 \mathrm{pm}$ to $8 \mathrm{pm}$ and on weekdays, the emissions of particle-associated PAH reached their highest levels on weekdays and during the afternoon, due to continued diesel burning in heavy-duty vehicles and particle resuspension associated with the traffic.

\section{Statistics and PAH diagnostic ratios}

It is reported that PAH can be used as source tracers. For example, ACE, FLT, PYR and CRY are predominant species in diesel emissions while ANT, BgP, BkF, BbF, PYR and $\mathrm{BaP}$ are the major species in gasoline emissions. ${ }^{35,36}$ Nevertheless, when considering recently published papers, it is easy to observe a significant overlap between them (e.g. IND, DBA and BgP are cited as originating from coal and kerosene combustion emissions but also from cigarette smoke), which makes ascertaining emission sources difficult. ${ }^{12,35-40}$ In this work, we have tentatively associated PAH designated as "source tracer" with Pearson correlations (Table 3), principal component analysis (Figure 5), cluster

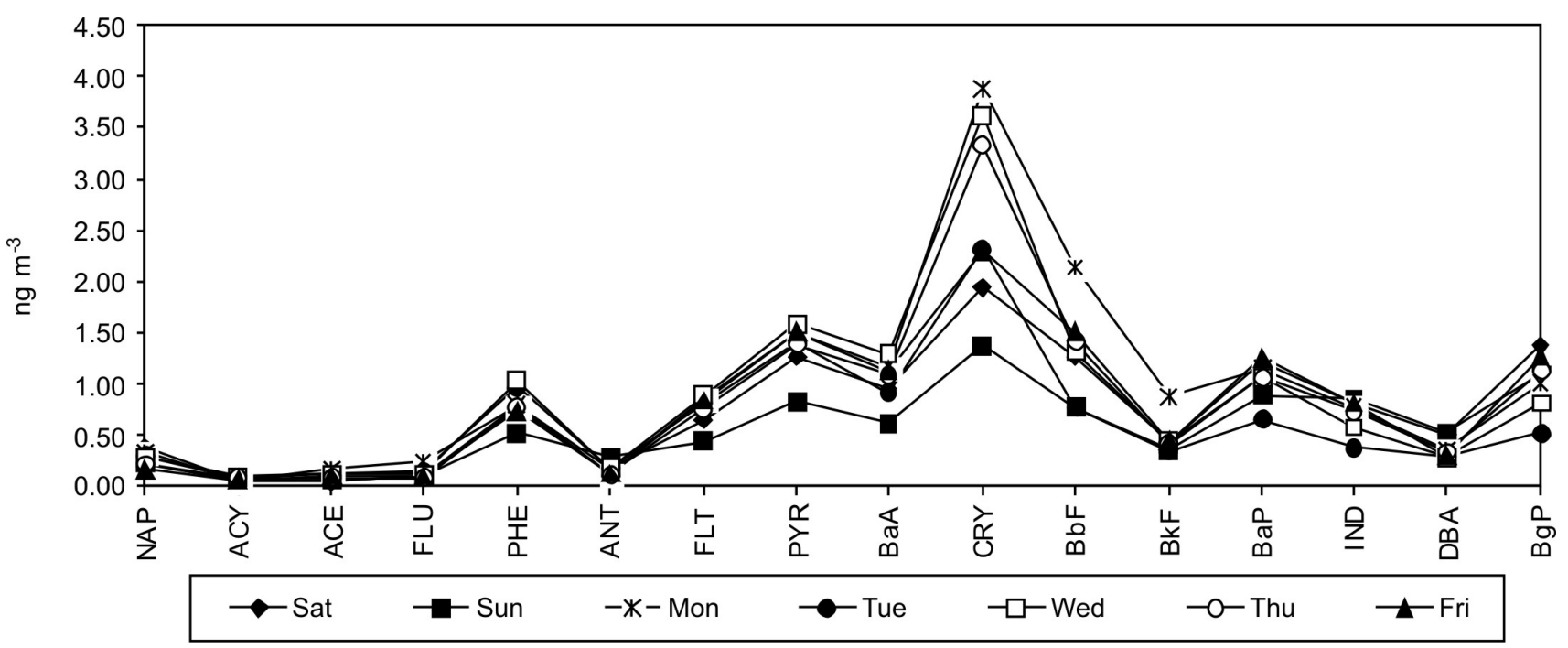

Figure 3. Comparison of mean $\mathrm{PM}_{10} \mathrm{PAH}$ concentrations on different days (each day represents a minimum of 3 values) from Lapa Bus Station.

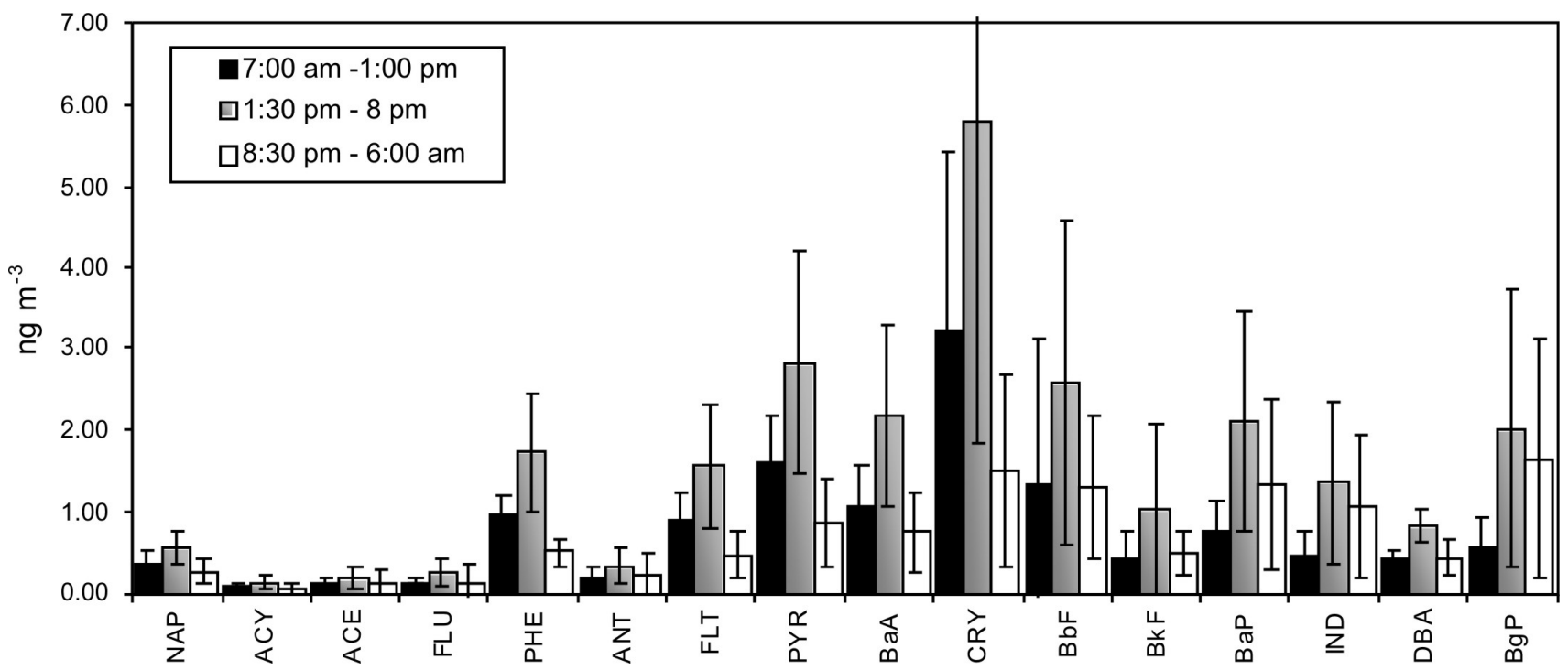

Figure 4. Contribution according to the period of the day for PAH concentrations at Lapa bus station $\left(\mathrm{PM}_{10}\right)$. 


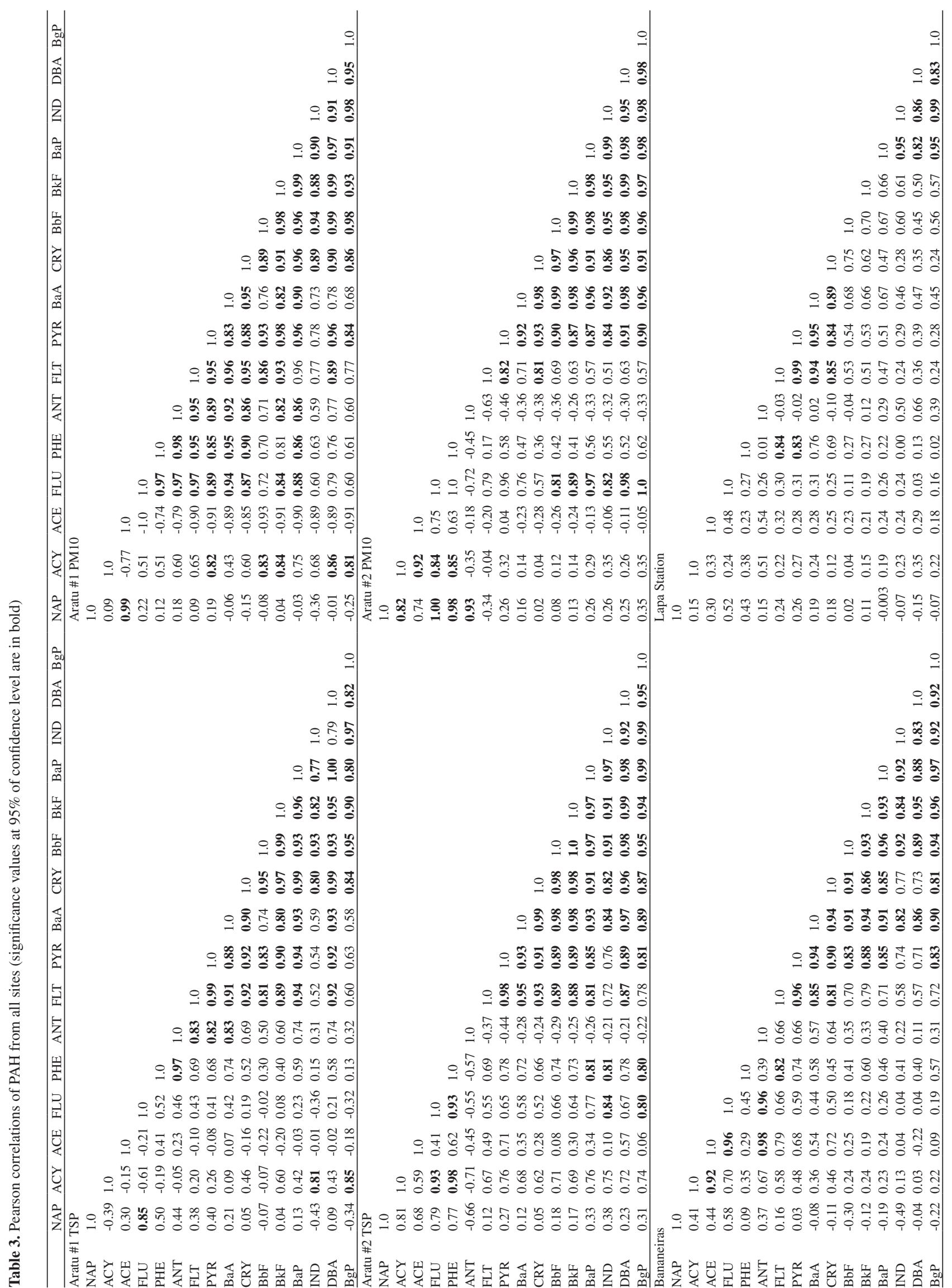


analysis (Figure 6), and diagnostic ratios (Table 4) in order to propose the major PAH sources for each site.
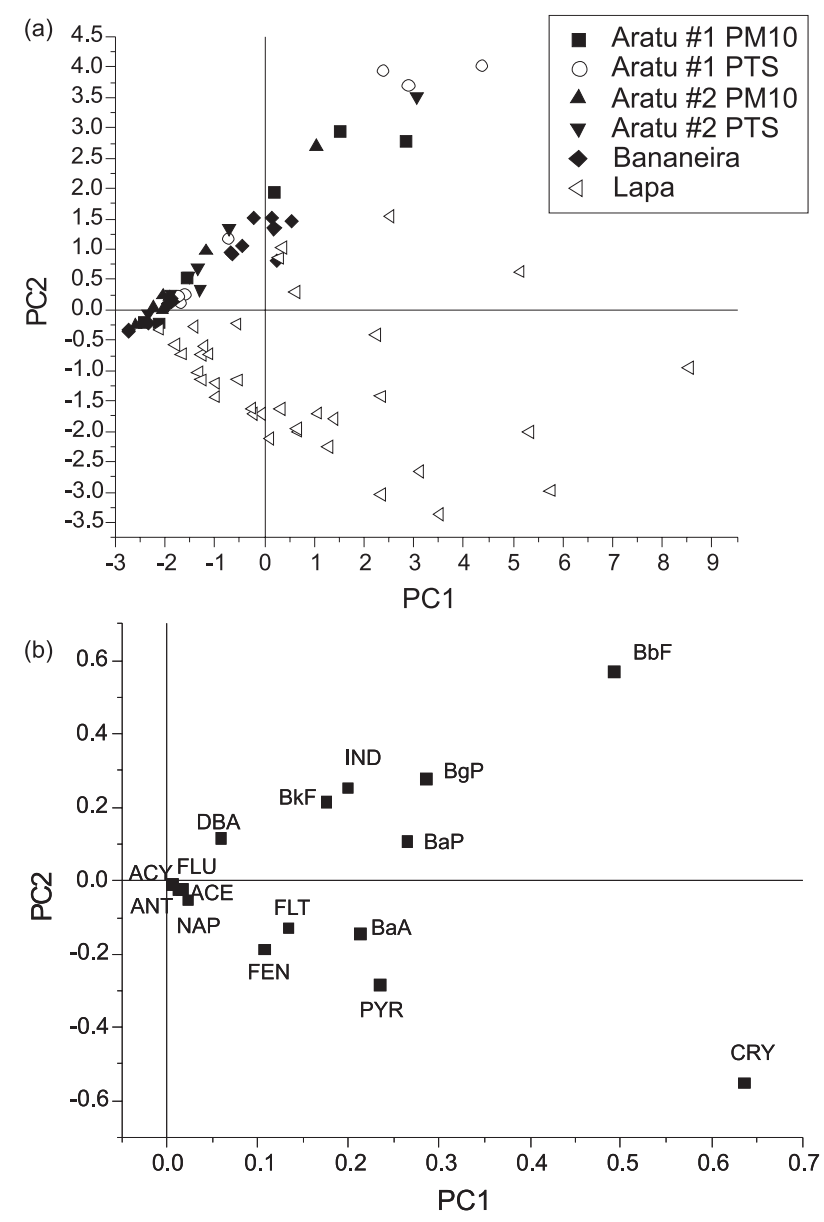

Figure 5. Principal component analysis according to (a) sampling sites, and (b) PAH (confidence level of 95\%, $\mathrm{n}=78$ ).
When considering Pearson correlations (Table 3) we have found, first, that both Aratu\#1 and Aratu \#2 TSP show two main correlation groupings: moderate-to-strong correlations among NAP, ACE, FLU, PHE and ANT $(0.44<\mathrm{r}<0.70)$ that could be representative of industrial emissions and/or petrol refinery from CIA and the industrial complex of Camaçari; and strong correlations for FLT, PYR, BaA, CRY, BbF, BkF, BaP, IND, DBA and BgP $(0.70<r<1.00)$ that may represent either gasoline or diesel emissions, although ACY, IND and BgP $(r>0.81)$ were well correlated only in Aratu \#1 TSP. Second, Aratu \#2 TSP ACY correlated with the more volatile species NAP, ACE and FLU ( $r>0.59)$. Aratu \#1 and Aratu \#2 $\mathrm{PM}_{10}$ presented higher Pearson scores and more PAH species in correlation with one another. Here the heavier species again show strong correlations among (PYR, FLU, BaA, CRY, BbF, $\mathrm{BkF}, \mathrm{BaP}, \mathrm{IND}, \mathrm{DBA}$ and $\mathrm{BgP}$ with $0.70<\mathrm{r}<0.99$ ). At this site we have tentatively attributed those correlations to industrial emissions and/or petrol refinery and gasoline or diesel emissions. Third, Bananeiras shows two distinct correlation groups, the former with weak-to-moderate correlations among NAP, ACY, ACE, FLU, PHE, and ANT $(0.37<\mathrm{r}<0.58$, which could be due to a petrol refinery, wood combustion for domestic heating/energy production) and the latter with moderate-to-strong correlations among FLT, PYR, BaA, CRY, BbF, BkF, BaP, IND, DBA and BgP $(0.81<r<0.96$, diesel exhausts from boats). Finally, Pearson correlations from Lapa Station have shown the lowest score values and the least species involved in correlations of all sites. This could denote more diverse PAH sources at that site, which would reflect into more difficult correlations between them, since more than one or two different sources should

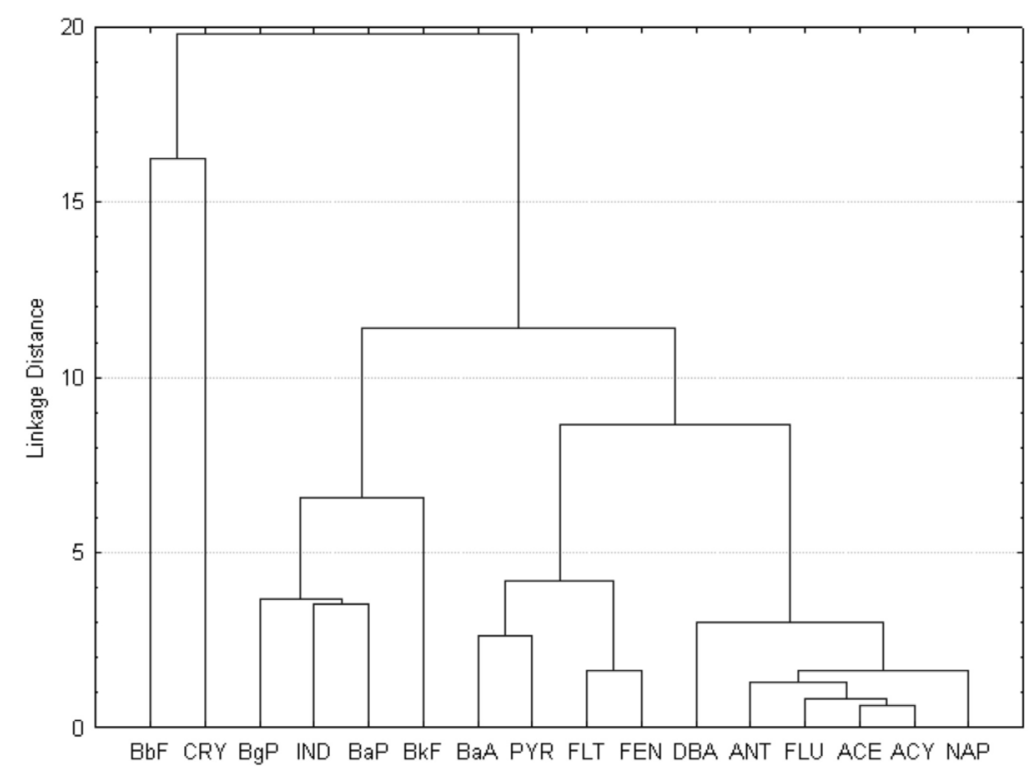

Figure 6. Cluster analysis for all sampling sites (confidence level of 95\%, $\mathrm{n}=78$ ). 
Table 4. PAH diagnostic ratios for this study, and for different sources ${ }^{\mathrm{a}}$

\begin{tabular}{|c|c|c|c|c|c|c|c|c|c|}
\hline & $\begin{array}{l}\text { FLT / } \\
\text { PYR }\end{array}$ & $\begin{array}{c}\mathrm{BbF}+\mathrm{BkF} / \\
\mathrm{BgP}\end{array}$ & $\begin{array}{l}\mathrm{BgP} / \\
\mathrm{IND}\end{array}$ & $\begin{array}{c}\mathrm{BaP} / \\
\mathrm{BgP}\end{array}$ & $\mathrm{BaA} / \mathrm{CRY}$ & $\begin{array}{c}\text { PYR / } \\
\mathrm{BaP}\end{array}$ & $\begin{array}{c}\text { FLT / } \\
\text { (FLT+PYR) }\end{array}$ & $\begin{array}{c}\mathrm{BaA} / \\
(\mathrm{BaA}+\mathrm{CRY})\end{array}$ & $\begin{array}{c}\text { IND / } \\
\text { (IND+BgP) }\end{array}$ \\
\hline \multicolumn{10}{|l|}{ SITES $^{a}$} \\
\hline Aratu \#1 TSP & 0.88 & 3.0 & 1.1 & 0.72 & 0.48 & 0.32 & 0.47 & 0.32 & 0.49 \\
\hline Aratu \#2 TSP & 0.94 & 2.5 & 1.1 & 0.60 & 0.43 & 0.29 & 0.49 & 0.30 & 0.47 \\
\hline Aratu \#1 $\mathrm{PM}_{10}$ & 1.0 & 3.2 & 1.1 & 0.73 & 0.51 & 0.34 & 0.50 & 0.34 & 0.48 \\
\hline Aratu \#2 $\mathrm{PM}_{10}$ & 0.87 & 2.4 & 1.1 & 0.60 & 0.50 & 0.37 & 0.47 & 0.33 & 0.47 \\
\hline Bananeira TSP & 0.94 & 3.2 & 1.2 & 0.88 & 0.53 & 0.38 & 0.48 & 0.35 & 0.45 \\
\hline Lapa bus station $\mathrm{PM}_{10}$ & 0.55 & 1.7 & 1.5 & 1.0 & 0.38 & 1.3 & 0.36 & 0.28 & 0.4 \\
\hline \multicolumn{10}{|l|}{ REPORTED SOURCES } \\
\hline Vehicles ${ }^{41,42,50,52,53}$ & & $0.20-1.72$ & $1.0-2.7$ & $0.3-0.78$ & 0.63 & & & & \\
\hline Gasoline exhaust $\mathrm{t}^{43,44,48-51}$ & $<1.0$ & 0.33 & $3.5-3.8$ & $0.3-0.4$ & $0.28-1.2$ & 0.85 & 0.43 & 0.37 & 0.18 \\
\hline Diesel exhaust ${ }^{45,46,49,52}$ & & 1.6 & $1.1-1.2$ & $0.46-0.81$ & $0.17-0.36$ & 0.81 & & 0.45 & 0.46 \\
\hline Wood combustion ${ }^{43,48,49}$ & 1 & & & & 0.93 & 0.71 & $0.56-0.67$ & $0.48-0.54$ & $0.58-0.69$ \\
\hline Rice straw combustion ${ }^{54,55}$ & & & 0.67 & 2 & & & & & 0.64 \\
\hline Coal combustion $22,44,46,49,50$ & 1.4 & & 1.1 & $0.9-6.6$ & $1.0-1.2$ & & & & \\
\hline Coke oven ${ }^{47}$ & & & & 5.1 & 0.7 & & & & \\
\hline Incinerators $^{42}$ & & & & $0.14-0.60$ & & & & & \\
\hline Petroleum refining ${ }^{42}$ & & & & $0.65-1.7$ & & & & & \\
\hline Domestic soot ${ }^{52}$ & & $1.5-14.0$ & & & & & & & \\
\hline
\end{tabular}

This study.

be participating in the origin of each PAH. At this site there are weak-to-moderate inter-correlations between NAP, ACY, ACE, FLU, PHE, FLT, PYR and BaA $(0.15<\mathrm{r}<0.84)$ and also moderate-to-strong correlations between PHE, FLT, PYR, CRY, BbF, BkF, BaP, IND, DBA and BgP $(0.51<\mathrm{r}<$ 0.99 , diesel exhausts from heavy-duty vehicles).

Figure 5 shows principal component analysis at $95 \%$ of confidence level for all sites jointly $(\mathrm{n}=78)$. From Figure 5a, PCA analysis shows that the first principal component explains $60 \%$ and the second accounts for $30 \%$ of all variance data, distinguishing two main groups according to similarities in the PAH emission patterns: the first group, formed by Aratu (\#1 and \#2 as well as TSP and $\mathrm{PM}_{10}$ ) and Bananeiras (TSP), and the second group, formed by samples from Lapa station. Compared to Lapa station samples, Aratu and Bananeiras samples would be expected to have both relatively high concentrations of those compounds with positive loadings (BbF, DBA, BkF, IND, BgP, and $\mathrm{BaP}$ ) on the first principal components and low concentrations of some other compounds with negative loadings (NAP, ACE, ACY, and FLU). Furthermore, Lapa samples have shown high concentrations and positive loadings for the second principal components $(\mathrm{BgP}, \mathrm{BaP}$, and $\mathrm{BbF}$ ) and both high concentrations and negative loadings for the second principal components (PHE, FLT, $\mathrm{BaA}, \mathrm{PYR}$, and CRY) (Figure 5b).
Considering that clusters with interpoint distances lower than 5\% of the greatest found distance show high similar profiles, the evaluation of Aratu \#1 and Aratu \#2 sites by cluster analysis pointed out that FLU, ACY, ANT, ACE, PHE, NAP, PYR and FLT presented highly similar profiles. The dendogram shown in Figure 6 brings out grouping tendencies of PAH that presented high similarities (i.e. low average Euclidian distances). In this way, four groups of PAH could be indicated by multivariate cluster analysis: (i) ACE, ACY, NAP, FLU, ANT, DBA; (ii) BaA, PYR, FLT, FEN; (iii) BbP, IND, BaP, BkF; and (iv) BbF, CRY. The group consisting of $\mathrm{BbF}$ and $\mathrm{CRY}$ was the must dissimilar one when compared with the other groups. By comparison, the grouping tendencies obtained by cluster analysis did not disagree with results attained using the Pearson correlation, showing that similar results were obtained by independent mathematical methods.

Molecular diagnostic ratios have been the most frequently used tool for source identification of atmospheric PAH. Although its reliability is still widely debated ${ }^{35}$ it is extensively employed..$^{32,36,37,56-58}$ Different sources release PAH in characteristic proportions that are not affected by vapor-to-particulate phase partitioning..$^{58-60}$ Table 5 compares the PAH ratios of this study with those reported by other researchers. First, the FLT/PYR, BaA/CRY, $\mathrm{FLT} /(\mathrm{FLT}+\mathrm{PYR}), \mathrm{BaA} /(\mathrm{BaA}+\mathrm{CRY})$ and IND/(IND+BgP) 
Table 5. Estimates of particle PAH dry deposition fluxes $\left(\mathrm{F}_{\mathrm{d}}\right)$

\begin{tabular}{|c|c|c|c|c|c|c|c|c|c|c|}
\hline & PYR & $\mathrm{BaA}$ & CRY & $\mathrm{BbF}$ & $\mathrm{BkF}$ & $\mathrm{BaP}$ & IND & DBA & $\mathrm{BgP}$ & $\Sigma \mathrm{PAH}$ \\
\hline Dry settling velocity, $\mathrm{V}_{\mathrm{d}} /\left(\mathrm{cm} \mathrm{s}^{-1}\right)^{*}$ & 0.2 & 0.35 & 0.54 & 0.55 & 0.62 & 0.71 & 0.89 & 0.76 & 0.97 & \\
\hline \multicolumn{11}{|l|}{ Aratu\#1 TSP } \\
\hline Geometric mean / $\left(\mathrm{ng} \mathrm{m}^{-3}\right)$ & 0.286 & 0.299 & 0.714 & 2.44 & 0.820 & 0.732 & 1.01 & 0.363 & 1.02 & \\
\hline Dry deposition flux, $\mathrm{F}_{\mathrm{d}} /\left(\mu \mathrm{g} \mathrm{m}^{-2}\right.$ day $\left.^{-1}\right)$ & 0.05 & 0.09 & 0.33 & 1.16 & 0.44 & 0.45 & 0.78 & 0.24 & 0.85 & 3.69 \\
\hline \multicolumn{11}{|l|}{ Aratu\#2 TSP } \\
\hline Geometric mean / $\left(\mathrm{ng} \mathrm{m}^{-3}\right)$ & 0.157 & 0.201 & 0.419 & 1.43 & 0.537 & 0.476 & 0.671 & 0.237 & 0.759 & \\
\hline Dry deposition flux, $\mathrm{F}_{\mathrm{d}} /\left(\mu \mathrm{g} \mathrm{m}^{-2}\right.$ day $\left.^{-1}\right)$ & 0.03 & 0.06 & 0.20 & 0.68 & 0.29 & 0.29 & 0.52 & 0.16 & 0.64 & 2.96 \\
\hline \multicolumn{11}{|l|}{ Aratu\#1 PM10 } \\
\hline Geometric mean / $\left(\mathrm{ng} \mathrm{m}^{-3}\right)$ & 0.189 & 0.225 & 0.491 & 1.53 & 0.592 & 0.489 & 0.596 & 0.227 & 0.644 & \\
\hline Dry deposition flux, $\mathrm{F}_{\mathrm{d}} /\left(\mu \mathrm{g} \mathrm{m}^{-2}\right.$ day $\left.^{-1}\right)$ & 0.03 & 0.07 & 0.23 & 0.73 & 0.32 & 0.30 & 0.46 & 0.15 & 0.54 & 2.94 \\
\hline \multicolumn{11}{|l|}{ Aratu\#2 PM10 } \\
\hline Geometric mean / $\left(\mathrm{ng} \mathrm{m}^{-3}\right)$ & 0.110 & 0.140 & 0.275 & 0.901 & 0.364 & 0.300 & 0.439 & 0.180 & 0.508 & \\
\hline Dry deposition flux, $\mathrm{F}_{\mathrm{d}} /\left(\mu \mathrm{g} \mathrm{m}^{-2}\right.$ day $\left.^{-1}\right)$ & 0.02 & 0.04 & 0.13 & 0.43 & 0.20 & 0.18 & 0.34 & 0.12 & 0.43 & 1.95 \\
\hline \multicolumn{11}{|l|}{ Bananeiras } \\
\hline Geometric mean / $\left(\mathrm{ng} \mathrm{m}^{-3}\right)$ & 0.211 & 0.241 & 0.432 & 1.13 & 0.512 & 0.473 & 0.499 & 0.229 & 0.529 & \\
\hline Dry deposition flux, $\mathrm{F}_{\mathrm{d}} /\left(\mu \mathrm{g} \mathrm{m}^{-2}\right.$ day $\left.^{-1}\right)$ & 0.04 & 0.07 & 0.20 & 0.54 & 0.27 & 0.29 & 0.38 & 0.15 & 0.44 & 2.50 \\
\hline \multicolumn{11}{|l|}{ Lapa } \\
\hline Geometric mean / $\left(\mathrm{ng} \mathrm{m}^{-3}\right)$ & 1.15 & 0.863 & 2.03 & 1.01 & 0.393 & 0.842 & 0.559 & 0.329 & 0.741 & \\
\hline Dry deposition flux, $\mathrm{F}_{\mathrm{d}} /\left(\mu \mathrm{g} \mathrm{m}^{-2}\right.$ day $\left.^{-1}\right)$ & 0.20 & 0.26 & 0.95 & 0.48 & 0.21 & 0.52 & 0.43 & 0.22 & 0.62 & 4.35 \\
\hline
\end{tabular}

ratios can be indicative of either gasoline exhaust from light-duty vehicles, diesel fuel burning on ships and from trucks, and coke discharge for Aratu \#1 TSP, Aratu \#2 TSP, Aratu \#1 PM10, and Aratu \#2 PM10. (BbF+BkF)/BgP seems to be a signature of domestic soot for samples of both fractions of PM from Aratu Harbor and Bananeiras, while for Lapa station it points to vehicle or diesel exhaust. Second, FLT/PYR (0.94) and FLT/(FLT+PYR) (0.48) for Bananeiras shows wood combustion (for energy production and slash clearance) sources; BgP/IND (1.2), $\mathrm{BaP} / \mathrm{BgP}(0.88)$ and IND/(IND+BgP) (0.45) are either coal combustion or diesel fuel burning on ships and boats. Finally, the ratios $\mathrm{BgP} / \mathrm{IND}$ (1.5), $(\mathrm{BbF}+\mathrm{BkF}) / \mathrm{BgP}(1.7)$, $\mathrm{BaP} / \mathrm{BgP}$ (1.0), $\mathrm{BaA} / \mathrm{CRY}$ (0.38), $\mathrm{BaA} /(\mathrm{BaA}+\mathrm{CRY})(0.28)$, and IND/(IND+BgP) (0.40) are broad signatures of diesel heavy-duty vehicles for Lapa station.

\section{Particle-associated PAHs dry deposition fluxes}

Dry atmospheric deposition fluxes $\left(\mathrm{F}_{\mathrm{d}}\right)$ were calculated by multiplying the geometric mean of each $\mathrm{PAH}$ concentration $\left(\mathrm{C}_{i}\right)$ in the particulate matter to PAH dry settling velocity $\left(\mathrm{V}_{\mathrm{d}}\right)$ as follow:

$\mathrm{F}_{\mathrm{d}}=\mathrm{C}_{i} \times \mathrm{V}_{\mathrm{d}}$

There are some uncertainties related to term $\mathrm{V}_{\mathrm{d}}$ since this may vary considerably due either to particle size, or to climatological or physical conditions in the atmosphere. In these cases, deposition velocity can vary 1-2 orders of magnitude. ${ }^{61-64}$ Even keeping in mind these uncertainties, the particulate matter dry deposition flux calculations bring broad but very helpful insights in order to better understand PAH removal mechanisms. Indeed, some authors have modeled $\mathrm{V}_{\mathrm{d}}{ }^{62,65}$ and they have found results comparable to those from Sheu et al. ${ }^{62}$ Therefore, in this study PAH particle dry depositions were calculated by using the $\mathrm{V}_{\mathrm{d}}$ stated in the latter study, as observed in Table 5.

Dry deposition flux for total PAH $\left(\mathrm{F}_{\mathrm{d}}\right.$ of $\left.\Sigma \mathrm{PAH}\right)$ showed the highest value $\left(4.35 \mu \mathrm{g} \mathrm{m}^{-2} \mathrm{day}^{-1}\right)$ for Lapa bus station, followed by Aratu \#2 TSP $\left(3.69 \mu \mathrm{g} \mathrm{m}^{-2}\right.$ day $\left.^{-1}\right)$, Aratu\#1 TSP $\left(2.96 \mu \mathrm{g} \mathrm{m}^{-2}\right.$ day $\left.^{-1}\right)$ and Aratu \#1 PM10 (2.93 $\mu \mathrm{g} \mathrm{m}^{-2}$ day $\left.^{-1}\right)$, Bananeiras $\left(2.49 \mu \mathrm{g} \mathrm{m}^{-2}\right.$ day $\left.^{-1}\right)$, and Aratu \#2 PM10 $\left(1.95 \mu \mathrm{g} \mathrm{m}^{-2} \mathrm{day}^{-1}\right)$. Individual deposition fluxes are found in Table 5. In most sites BbF was the PAH with the highest deposition flux followed by BgP and IND. The exception is made for Lapa Station where CRY, BgP, BaP and $\mathrm{BbF}$ demonstrated higher $\mathrm{F}_{\mathrm{d}}$ loadings.

The apparent dry deposition fluxes from Table 5 take into account both the geometric averaged concentration level of an individual PAH sorbed on to particulate matter and dry deposition velocity. They should also take into account the PAH reactivity that can be an important parameter in interpreting the dataset. Nielsen ${ }^{65}$ has developed a reactivity scale that groups PAH into five classes of reactivity (from Class I, the most reactive group, 
to Class V, the least reactive ones) toward nitrating species generating either nitro-PAHs, oxy-PAHs or quinones (these are $\mathrm{PAH}$ derivatives that are much more carcinogenic and/or mutagenic than those species from which they originated, so are of more concern in health issues). If a PAH is more reactive than others, it is more easily modified (removed) by a photochemical reaction and it would not be found in PM in high levels so that dry or wet deposition mechanisms would not be its main atmospheric fate. On the other hand, the less reactive the species, the more probable the PAH is to sink by either dry or wet deposition, depending on its vapor pressure and water solubility (being, therefore, incorporated into terrestrial and/or aquatic systems). This should be considered when analyzing some isomer pairs such as PHE and ANT, FLT and PYR, BbF and BkF, and IND and DBA. PHE belongs to Class V and ANT is Class II. Thus it is reasonable to accept that ANT, being more reactive than PHE, would be more readily modified to any of its possible nitro-derivatives, so that less ANT would be available for dry deposition. ${ }^{66}$ The same happens with the next two isomer pairs: (i) FLT (Class V) and PYR (Class III), and (ii) IND (Class V) and DBA (Class IV), where PYR and DBA, respectively, apparently possess lower dry deposition fluxes. In the case of the $\mathrm{BbF}$ and $\mathrm{BkF}$ pair, both belong to the same reactivity class (Class V) and the high fluxes are derivated from both high concentration levels and deposition velocities. Summing up, if dry deposition was the main removal mechanism for PHE, FLT, IND, BbF, $\mathrm{BkF}$ and in minor extension, for DBA (and the other Class IV, CRY), these airborne particles, once deposited, might be resuspended by any mechanical/physical perturbation being then able to be enriched by some freshly generated PAH (vapor-PAH converted to particle) or by any physical interaction such as accumulation, coagulation, etc., acting in both freshly and aged particulate PAH and be again dry deposited. This cyclic path of those PAH could happen continuously and the particulate matter could be aged in relation to some less reactive PAH. The same might happen with NAP, ACY, and, tentatively, to ACE and FLU that also are classified as Class V species. But in this case, because they are preferentially segregated to the gaseous phase, their principal fate would be gaseous dry deposition or even wet deposition, since they are also the most water soluble of the 16 priority $\mathrm{PAH}$.

\section{Conclusions}

The present work has aimed to determine the atmospheric concentrations and profiles of 16 particle-phase US EPA priority PAH pollutants, present at three sites of Salvador, BA, Brazil: (i) Lapa bus station, strongly impacted by heavy-duty diesel vehicles; (ii) Aratu Harbor, impacted by an intense movement of goods, including coke, metal ores and chemicals and near industrial centers; and (iii) Bananeira village, located on Maré Island, a non vehicleinfluenced site, with activities such as handcraft work and fisheries, although located near the port. The contributions of carcinogenic species for the total PAH content, the Pearson's correlations of PAH from all sites, source apportionment and dry deposition flux for the total PAH were reported and discussed.

Results pointed out that, considering all sampling days, $\mathrm{BbF}\left(0.130-6.85 \mathrm{ng} \mathrm{m}^{-3}\right)$ is the PAH with highest concentration in samples from Bananeira and Aratu Harbor CRY (from 0.075 to $6.85 \mathrm{ng} \mathrm{m}^{-3}$ ) was the one that presented higher concentrations in Lapa bus station. At these sites, on average, $\Sigma \mathrm{PAH}$ accounted for $0.005 \%$ and $0.0012 \%$ of the TSP mass for Aratu Harbor and Bananeiras village, respectively, while it was $0.008 \%$ and $0.011 \%$ of the PM10 mass of Aratu Harbor and Lapa bus station, respectively. Particle content of the particulate phase was (in $\mu \mathrm{g} \mathrm{g}^{-1}$ ): 61.2, 38.1, 113.7, 39.2, 118.6, and 112.6 for Aratu \#1 TSP, Aratu \#2 TSP, Aratu \#1 $\mathrm{PM}_{10}$, Aratu \#2 $\mathrm{PM}_{10}$, Bananeiras, and Lapa station, respectively. Contributions of carcinogenic species (BaA, BbF, BkF, BaP, DBA, and IND) to $\mathrm{PAH}$ content represent (in $\mu \mathrm{g} \mathrm{g}^{-1}$ ) 42.4, 25.4, 78.2, 25.2, 79.4 and 45.3 for Aratu \#1 TSP, Aratu \#2 TSP, Aratu \#1 PM 10 , Aratu \#2 $\mathrm{PM}_{10}$, Bananeiras and Lapa, respectively. PAH sources from the studied sites were mainly of anthropogenic origin, Aratu \#1 (TSP and $\mathrm{PM}_{10}$ ) had as PAH sources automobile traffic (gasoline fueled light-duty vehicles and diesel fueled heavy-duty vehicles), discharges in the port (coke and others), and domestic/office soot. Aratu \#2 (TSP and $\mathrm{PM}_{10}$ ) is impacted by the following PAH sources: automobile traffic (gasoline fueled light-duty vehicles and diesel fueled heavy-duty vehicles) and discharges in the port (coke and others). Bananeiras, although being a remote site, had PAH sources such as: diesel burning from ships and smaller boats, domestic soot, coal and wood combustion for energy production. Finally, Lapa station presented the following main PAH sources: emissions from diesel fueled heavy-duty vehicles; cooking emission from cafeterias and restaurants at the station and, finally, dust resuspension through circulation of buses and people and exchange of dust from the area surrounding the station.

Dry deposition flux for the total PAH ( $\mathrm{F}_{\mathrm{d}}$ of $\left.\Sigma \mathrm{PAH}\right)$ showed the highest value $\left(4.35 \mu \mathrm{g} \mathrm{m}^{-2} \mathrm{day}^{-1}\right)$ for Lapa bus station, followed by Aratu \#2 TSP $\left(3.69 \mu \mathrm{g} \mathrm{m}^{-2} \mathrm{day}^{-1}\right)$, Aratu\#1 TSP (2.96 $\mu \mathrm{g} \mathrm{m}^{-2}$ day $\left.^{-1}\right)$ and Aratu \#1 PM10 (2.93 $\mu \mathrm{g} \mathrm{m}^{-2}$ day $\left.^{-1}\right)$, Bananeiras $\left(2.49 \mu \mathrm{g} \mathrm{m}^{-2}\right.$ day $\left.^{-1}\right)$, and Aratu \#2 PM10 $\left(1.95 \mu \mathrm{g} \mathrm{m}^{-2}\right.$ day $\left.^{-1}\right)$. In most sites BbF was the $\mathrm{PAH}$ with the highest deposition flux followed by $\mathrm{BgP}$ 
and IND. Exception is made for Lapa station where CRY, $\mathrm{BgP}, \mathrm{BaP}$ and $\mathrm{BbF}$ demonstrated higher $\mathrm{F}_{\mathrm{d}}$ loadings.

\section{Acknowledgments}

Authors are grateful to CNPq, CAPES, FINEP, FAPESB, PRONEX, RECOMBIO, Nordeste Generation, and ANEEL for financial support to this study and to Nei de C. Bahia for his helpful assistance.

\section{References}

1. Cho, A. K.; Sioutas, C.; Miguel, A. H.; Kumagai, Y.; Schmitz, D. A.; Singh, M.; Eiguren-Fernandez, A.; Froines, J. R; Environ. Res. 2005, 99, 40.

2. Pope, C. A.; Burnett, R. T.; Thun, M. J.; Calle, E. E.; Krewski, D.; Ito, K.; Thurston. G. D.; J. Am. Med. Assoc. (JAMA) 2002, 287, 1132 .

3. W. A. Lopes; J. B de Andrade.; Quim. Nova 1996, 19, 497.

4. Vanrullen, I.; Chaumontet, C.; Pornet, P.; Véran, F.; Martel, P.; Environ. Sci. Technol. 2000, 34, 1352.

5. Pereira Netto, A. D.; Moreira, J. C.; Dias, A. E. X. O.; Arbilla, G.; Ferreira, L. F. V.; Oliveira, A. S.; Barek, J.; Quim. Nova 2000, 23, 765 .

6. Halinen, A. J.; Komulainen, H.; Salonen, R. O.; Ruotsalainen, M.; Hirvonen, M.; Environ. Toxicol. Pharmacol. 1999, 7, 11.

7. Sumi, D.; Kumagai, Y.; Yakugaku Zasshi 2007, 127, 1949.

8. Miguel, A. H.; de Andrade, J. B.; Hering, S.V.; Int. J. Environ. Anal. Chem. 1986, 26, 265.

9. Miguel, A. H.; Kirchstetter, T. W.; Harley, R. A.; Hering, S. V.; Environ. Sci. Technol. 1998, 32, 450.

10. Ravindra, K.; Wauters, E.; Van Grieken, R.; Sci. Total. Environ. 2008, 396, 100.

11. Liu, X.; Zang, G.; Li, J.; Sheng, H-R.; Qi, S-H.; Li, X-D.; Jones, K.C.; J. Environ. Monit. 2007, 9, 1092.

12. Chen, Y.; Ho, K. F.; Ho, S. S. H.; Ho, W. K.; Lee, S. C.; Yub, J. Z.; Sit, E. H. L.; J. Environ. Monit. 2007, 9, 1402.

13. Wang, D.; Yang, M.; Jia, H.; Zhou, L.; Li, Y.; J. Environ. Monit. 2008, 10, 1076.

14. Boll, E. S.; Christensen, J. H.; Holm, P. E.; J. Environ. Monit. 2008, 10, 261.

15. Vione, D.; Barra, S.; de Gennaro, G.; de Rienzo, M.; Gilardoni, S.; Perrone, M. G.; Pozzoli, L.; Anal. Chim. 2004, 94, 257.

16. Pozzoli, L.; Gilardoni, S.; Perrone, M. G.; De Gennaro, G.; De Rienzo, M.; Vione, D.; Anal. Chim. 2004, 94, 17.

17. Dunbar, J. C.; Lin, C. I.; Vergucht, I.; Wong, J.; Durant, J. L.; Sci. Total Environ. 2001, 279, 1.

18. Jacob, J.; Karcher, W.; Belliardo, J. J.; Dumler, R.; Boenke, A.; Fresenius J. Anal. Chem. 1991, 340, 755.

19. Bjorseth, A.; Handbook of Polycyclic Aromatic Hydrocarbons, Marcel Dekker, Inc.: New York, 1983.
20. Magalhães, D.; Bruns, R. E.; Vasconcellos, P. C.; Quím. Nova 2007, 30, 577.

21. Phuleria, H. C.; Geller, M. D.; Fine, P. M.; Sioutas, C.; Environ. Sci. Technol. 2006, 40, 4109.

22. UK Government Expert Panel on Air Quality Standards, available on http://www.airquality.co.uk/archive/standards. php\#std, accessed in February 2008.

23. Shah, S. D.; Ogunyoku, T. A.; Miller, J. W.; Cocker, D. R.; Environ. Sci. Technol. 2005, 39, 5276.

24. Marr, L. C.; Kirchstetter, T. W.; Harley, R. A.; Miguel, A. H.; Hering, S. V.; Hammond, S. K.; Environ. Sci. Technol. 1999, 33, 3091 .

25. Allen, J. O.; Dookeran, N. M.; Smith, K. A.; Sarofim, A. F.; Taghizadeh, K.; Lafleur, A. L.; Environ. Sci. Technol. 1996, 30 , 1023.

26. Venkataraman, C.; Lyons, J. M.; Friedlander, S. K.; Environ. Sci. Technol. 1994, 28, 555.

27. Pereira, P. A. P.; Lopes, W. A.; Carvalho, L. S.; da Rocha, G. O.; Bahia, N. C.; Loyola, J.; Quiterio, S. L.; Escaladeira, V.; Arbilla. G.; de Andrade, J. B.; Atmos. Environ. 2007, 41, 7837.

28. Pereira, P. A. P.; de Andrade, J. B.; Miguel, A. H.; J. Environ. Monit. 2002, 4, 558.

29. Method IO-3.1; Compendium of Methods for the Determination of Inorganic Compounds in Ambient Air; Selection, Preparation and Extraction of Filter Material, EPA, 1999.

30. Pereira, P. A. P.; de Andrade; J. B.; Miguel, A. H.; Anal. Sci. 2001, 17, 1229.

31. Lopes, W. A.; da Rocha, G. O.; Pereira, P. A. P.; Oliveira, F. S.; Carvalho, L. S.; Bahia, N. C.; Conceição, L. S.; de Andrade, J. B.; J. Sep. Sci. 2008, 31, 1787.

32. Wu, S-P.; Tao, S.; Zhang, Z-H.; Lan, T.; Zuo, Q.; Environ. Pollut. 2007, 147, 203.

33. Bae, S. Y.; Yi, S. M.; Kim, Y. P.; Atmos. Environ. 2002, 36, 5491.

34. Allen, A. G.; da Rocha, G. O.; Cardoso, A. A.; Paterlini, W.; Machado, C. M. D.; de Andrade, J. B.; Transp. Res. Part D: Transp. Environ. 2008, 13, 483.

35. Fon, T. Y. W.; Noriatsu, O.; Hiroshi, S.; Water, Air, Soil Pollut. 2007, 182, 235.

36. Motelay-Massei, A.; Ollivon, D.; Garban, B.; Tiphagne-Larcher, K.; Zimmerlin, I.; Chevreuil, M.; Chemosphere 2007, 67, 312.

37. Vasconcellos, P. C.; Zacarias, D.; Pires, M. A. F.; Pool, C. S.; Carvalho, L. R. F.; Atmos. Environ. 2003, 37, 3009.

38. Harrison, R. M.; Smith, D. J. T.; Luhana, L.; Environ. Sci. Technol. 1996, 30, 825.

39. Baek, S-O.; Jenkins, R. A.; Atmos. Environ. 2004, 38, 6583.

40. Ding, Y. S.; Trommel, J. S.; Yan, X. J.; Ashley, D.; Watson, C. H.; Environ. Sci. Technol. 2005, 39, 471.

41. Daisey, J. M.; Leyko, M. A.; Kneip, T. J.; Polynuclear Aromatic Hydrocarbons, Jones, P.W.; Leber, P., eds., Ann Arbor, 1979, p. 201. 
42. Smith, D. J. T.; Harrison, R. M.; Atmos. Environ. 1996, 30, 2513.

43. Gschwend, P. M.; Hites, R. A.; Geochim. Cosmochim. Acta 1981, 45, 2359.

44. Rogge, W. F.; Hildemann, L. M.; Mazurek, M. A.; Cass, G. R.; Simoneit, B. R. T.; Environ. Sci. Technol. 1993, 27, 636.

45. Westerholm, R. N.; Almen, J.; Li, H.; Rannug, J. U.; Egeback, K. E.; Gragg, K.; Environ. Sci. Technol. 1991, 25, 332.

46. Masclet, P.; Bresson, M. A.; Mouvier, G.; Fuel 1987, 66, 556.

47. Khalili, N. R.; Scheff, P. A.; ;Holsen, T. M.; Atmos. Environ. 1995, 29, 533.

48. Stroher, G. L.; Poppi, N. R.; Raposo, J. L. Jr.; de Souza, J. B. G.; Microchem. J. 2007, 86, 112.

49. Lee, M. L.; Vassilaros, D. L.; Later, D. W.; Int. J. Environ. Anal. Chem. 1982, 11, 251.

50. Jaklin, J.; Krenmayr, P.; Int. J. Environ. Anal. Chem. 1985, 21, 33.

51. Li, C. K.; Kamens, R. M.; Atmos. Environ. 1993, 27, 523.

52. Cretney, J. R.; Lee, H. K.; Wright, G. J.; Swallow, W. H.; Taylor, M. C.; Environ. Sci. Technol. 1985, 19, 397.

53. Ohura, T.; Amagai, T.; Fusaya, M.; Matsushita, H.; Environ. Sci. Technol. 2004, 38, 77.

54. Jenkins, B. M.; Jones, A. D.; Turn, S. Q.; Williams, R. B.; Environ. Sci. Technol. 1996, 30, 2462.

55. Jenkins, B. M.; Jones, A. D.; Turn, S. Q.; Williams, R. B.; Atmos. Environ. 1996, 30, 3825.
56. Simcik, M. F.; Eisenreich, S. J.; Lioy, P. J.; Atmos. Environ. 1999, 33, 5071.

57. Kakimoto, H.; Yutaka, M.; Sakai, S.; Kanoh, F.; Arashidani, K.; Tang, N.; Akutsu, K.; Nakajima, A.; Awata, Y.; Toriba, A.; Kizu, R.; Hayakawa, K.; J. Health Sci. 2002, 48, 370.

58. Ding, Y. S.; Ashley, D. L.; Watson, C. H.; J. Agric. Food Chem. 2007, 55, 5966.

59. Ding, X.; Wang, X. M.; Xie, Z. Q.; Xiang, C. H.; Mai, B. X.; Sun, L. G.; Zheng, M.; Sheng, G. Y.; Fu, J. M.; Poschl, U.; Atmos. Environ. 2007, 41, 2061.

60. Schauer, J. J.; Rogge, W. F.; Hildemann, L. M.; Mazurek, M. A.; Cass, G. R.; Simoneit, B. R. T.; Atmos. Environ. 1996, 30, 3837.

61. Vardar, N.; Odabasi, M.; Holsen, T. M.; J. Environ. Eng. 2002, $128,269$.

62. Sheu, H-L.; Lee, W-J.; Su, C-C.; Chao, H-R.; Fan, Y-C.; J. Environ. Eng. 1996, 122, 1101.

63. Fang, G-C.; Chang, K-F.; Lu, C.; Bai, H.; Chemosphere 2004, $55,787$.

64. Chang, K-F.; Fang, G-C.; Lu, C.; Bai, H.; Aerosol Air Qual. Res. 2003, 3, 41.

65. Nielsen, T.; Environ. Sci. Technol. 1984, 18, 157.

66. Tasdemir, Y.; Esen, F.; Atmos. Environ. 2007, 41, 1288.

Received: October 17, 2008

Web Release Date: April 24, 2009

FAPESP helped in meeting the publication costs of this article. 